\title{
Hospitalitas Kristen Sebagai Upaya Melibatkan Pemuda Dalam Pelayanan Jemaat
}

\author{
Oktavia Tapang \\ INSTITUT AGAMA KRISTEN NEGERI TORAJA
}

oktaviatapang10@gmail.com

Abstract : Worship is a process to get closer to God through praise and is based on expressions of gratitude for God's goodness and helps us to know God better and be faithful to God's call. Considering the life of the people, many young people today do not understand the meaning of worship and are vulnerable to falling (committing sins) because they are seen as a period of selfdiscovery. Therefore, youths are required to be involved in ministry and youth ministry and fellowship must always be accompanied and guided by the pastor of the congregation so that today's youth grow and develop in accordance with the character of Christ. Every believer must understand the basics of believer's worship, namely the blood of Jesus that has been shed for humans who have also become a substitute for an offering to come to God and Jesus as great faith.

Abstrak : Ibadah sebagai proses untuk mendekatkan diri kepada Tuhan melalui puji-pujian dan dilandasi dengan ungkapan syukur karena kebaikan Tuhan dan membantu kita untuk lebih mengenal Tuhan dan setia akan panggilan Tuhan. Mengingat kehidupan kaum, muda saat ini banyak yang kurang memahami tentang makna beribadah dan rentan untuk jatuh (melakukan dosa) karena di anggap sebagai masa pencarian jati diri. Oleh karena itu pemuda di haruskan untuk melibatkan diri dalam pelayanan dan panggilan dan persekutuan pemuda harus selalu di damping dan di bimbing oleh gembala jemaat agar pemuda saat ini tumbuh dan berkembang sesuai dengan karakter kristus. Setiap orang percaya harus mengerti dasar-dasar ibadah orang percaya yaitu darah Yesus yang telah di curahkan bagi manusia yang juga telah menjadi pengganti korban persembahan untuk datang menghampiri Allah dan Yesus sebagai Iman besar.

Kata Kunci : Gereja, Ibadah, Persekutuan, Pemuda

\section{PENDAHULUAN}

Masa muda adalah masa yang paling berpotensi dalam tahap kehidupan manusia gereja harus menjadikan pemuda sebagai tiang yang utama dalam gereja. Perkembangan zaman yang begitu pesat sangat mempengaruhi kehidupan manusia secara khusus untuk kaum muda Kristen. Oleh sebab itu, badan pengurus jemaat haruslah menjalankan perannya sebagai pelayan Tuhan, untuk meningkatkan pertumbuhan kerohanian pemuda. Pelayanan kepada pemuda untuk meningkatkan pertumbuhan kerohanian pemuda sangatlah penting dan menentukan masa depan gereja yang dilakukan oleh badan pengurus jemaat. Pelayanan yang dilakukan oleh badan pengurus jemaat kepada pemuda Kristen dalam gereja untuk 
membimbing dan menolong setiap kaum muda dalam gereja untuk pembentukan kepribadiannya sesuai dengan standar Firman Tuhan. Oleh sebab itu, setiap pemuda di gereja membutuhkan pelayan Tuhan yang benarbenar ingin melayani pemuda, khususnya badan pengurus jemaat telah ditunjuk oleh jemaat untuk melayani dan menangani pemuda dalam gereja. Dalam meningkatkan pertumbuhan kerohanian pemuda untuk pengenalan akan Yesus Kristus, badan pengurus jemaat harus mempedulikan dan berperan aktif untuk pemuda agar mereka tidak terbawa oleh arus dunia ini. Selain dari itu, badan pengurus jemaat harus menjalankan perannya sebagai pelayan Tuhan dalam meningkatkan pertumbuhan kerohanian pemuda. Pelayanan kepada pemuda untuk meningkatkan kerohanian mereka yang dilakukan oleh badan pengurus jemaat kepada pemuda sangatlah penting untuk dilakukan karena pemuda merupakan bagian yang terpenting di dalam gereja, dan masa muda adalah masa transisi di mana kaum muda sangat membutuhkan bimbingan.

Salah satu indikator yang di gunakan dalam Melihat keberhasilan sebuah gereja adalah jumlah persentase jemaat yang Melayani tidak terkecuali para generasi Muda, bagaimana keterlibatan pemuda dalam pelayanan gereja?

7 dari 10 generasi Muda Kristen di jemaat yang rutin terlibat dalam pelayanan, rata-rata itu sebagai pengurus, persentase yang Melayani di gereja itu rata-rata lebih banyak perempuan dari pada laki-laki. Mereka yang terlibat dalam pelayanan lebih untuk berinteraksi tentang Yesus dan Mengajak untuk Mengikut Yesus di bandingkan dengan yang hanya saling Mengisi, selain itu ada juga yang Mungkin untuk membimbing dan Menolong pertumbuhan kerohanian orang lain.

Keikutsertaan dalam pelayanan juga berdampak positif bagi pemuda dalam kedisiplinan rohani Kristen

\section{TUJUAN DAN MANFAAT}

\section{a. Tujuan penulisan}

Berdasarkan latar belakang masalah di atas, maka rumusan masalah yang dapat disusun, yakni: bagaimana peran pemuda dalam melibatkan diri dalam pelayanan jemaat dalam meningkatkan pertumbuhan kerohanian pemuda Gereja Kristen.

\section{b. Manfaat penulisan}

Manfaat yang diperoleh dari hasil penelitian ini ialah dapat membentuk karakter kaum muda dan menjadikan mereka sebagai murid kristus yang dewasa dalam iman serta mengaplikasikan setiap ajaran tentang firman Allah yang telah didapatkan dalam panggilan dan kesetiaan pemuda dalam beribadah.

\section{PEMBAHASAN}


Manusia Merupakan Makhluk hidp yang selalu berinteraksi dengan sesama, dalaM kehidupan Manusia MeMerlukan pula adanya organisasi. Gereja adalah orang-orang percaya kepada Kristus dan telah dibaptis (UBK : Umat Beriman Kristiani). Sementara itu, persekutuan dapat diartikan sebagai sebuah persekutuan dapat diartikan sebagai situasi akrab dan bersahabat dalam sebuah ikatan tertentu. Gereja sebagai persekutan artinya orang-orang yang percaya kepada Kristus dan telah dibaptis yang terikat dan berinteraksi satu sama dalam ikatan kasih Kristus. "Geraja yang diutuss oleh kristus untuk memperlihatkan dan menyalurkan cinta kasih Allah kepada semua orang dan segala bangsa, menyadari bahwa karya Allah harus dilaksanakan memang sangat berat.

Pemuda dan masa depan, ibarat "manusia dan udara", adalah dua hal yang tidak dapat dipisahkan karena telah menjadi kodrat bagi pemuda sendiri, yang seting disebut-sebut sebagai masa depan, tunas bangsa, dan pelanjut generasi, sejarah telah membuktikan bahwa pemuda turut berdiri dalam rangkaian upaya pembangunan bangsa. Bahkan ketika kita berbicara tentang sejarah bangsa Indonesia, pembicaraan tersebut tidak bisa terlepas dari konteks kepemudaan. Ada banyak pendapat yang berkembang di tengah-tengah kehidupan masyarakat Indonesia mengatakan bahwa sebagian besar generasi muda Indonesia berada dalam keadaan acuh tak acuh, hidup santai, miskin dalam cita-cita, mengalami erosi idealisme dan patriotism. Berbicara dalam konteks gereja, kondisi pemuda juga mengalami hal yang sama. Bisa di lihat minimnya peran serta pemuda untuk dapat melayani di gereja menjadi cerminan bagaimana usaha suatu gereja mengakomodasi potensi yang dimiliki oleh kaum mudanya. Keaktifaan organisasi kategori pemuda gereja juga bisa menjadi indikator penilaian terhadap kepedulian gereja terhaddap kaum mudanya. Minimnya pendeta pemuda, kurang perhatian dann berbagai hal lainnya menjadi realitas yang di hadapi pemuda dalam gereja saat ini. Dalam konteks berbangsa, peran dan tanggung jawab pemuda Kristen sangarr besar. Pemuda Kristen harus berani menempatkan kesejahteran, keadilan, kebenaran, keutuhan ciptaan dan demokrasi di Indonesia yang berdasarkan dengan kasih. Dengan kata lain pemuda Kristen harus menjadi pelopor terwujudnya "shalom Allah" di muka bumi ini. Hal ini akan menunjukkan bagaimana pemuda Kristen merelevansikan imannya di tengah-tengah kehidupan dunia. Oleh karena itu, konsep persekutuan dan nasionalisme merupakan dua hal yang sangat berkaitan dan dua hal ini sepatutnya di miliki oleh pribadi pemuda Kristen. Pemuda Kristen di tuntut meningkatkan ketekunan dalam kejujuran, mengasag setiap potensi yang dimiliki dan menyalurkan kreativitas yang mengarah pada pembangunan bangsa Indonesia. Sebagian bagian dari anggota tubuh kristus, generasi muda di gereja seharusnya ikut berperan aktif bekerja melayani Tuhan. Mereka akan menjadi anggota gereja yang baik dan peran di masyarakat sebagai saksi kristus.

\section{a. Perkembangan Pemuda Dalam Negara}

Pemuda merupakan bahan bakar atau sebuah lokomotif yang dapat menjadi energi untuk menjalankan roda kehidupan berbangsa dan bernegara. Dari sikap kritis dan rasa ingin tahu itulah pemuda selalu berpeluang besardalam mengawal perjalan bangsa kedepan, 
inilah yang penulis sebut sebagai melihat ancaman dan menakar peluang. Ancaman tersebut tentulah bukanlah peperangan seperti masa colonial dulu, melainkan melawan zaman yang semakin canggih, serta evolusi teknologi yang selalu membayangi. Termasuk dalam mekanisme waktu tersebutlah yang menjadi tantangan kaum muda dapat memanfaatkanya sebagai peluang atau justru malah terpenjara dalam cengkraman nafsu dan fanatisme. Disinilah perlunya memberi peran pemuda dalam memanfaatkan peluang besaritu sebagai nilai yang positif.

\section{b. Perkembangan Pemuda Rohani}

Perkembangan era digital yang semakin pesat saat ini telah mempengaruhi kehidupan rohani manusia. Di tengah kecanggihan cara berkomunikasi yang mempermudah kehidupan manusia dan meningkatnya kesejahteraan bangsa Indonesia. Idealnya jemaat Tuhan mengucap syukur seperti tertulis dalam Efesus 5:20. Ucaplah syukur senantiasa atas segala sesuatu dalam nama Tuhan kita Yesus Kristus kepada Allah dan Bapa kita. Namun, dalam kenyaatannya kehidupan rohani jemaar Tuhan di Indonesia khususnya para pemuda di kota. Dimana maraknya kasus kenakalan pemuda seperti penyalagunaan narkoba, kehamilan di luar nikah, tawuran antar pemuda, mabuk-mabukan adalah beberapa contoh persoalan sosial pemuda yang dihadapi bangsa Indonesia saat ini. Pemuda Kristen tak terkecuali juga menjadi penyumbang dari kasus persoalan tersebut. Kehidupan rohani pemuda tersebut harus diubah dratis melalui sebuah tindakan nyata dari semua pihak, tidak hanya oleh para pemuda saja namun perlu upaya yang berssama orang tidak hanya oleh para pemuda saja namun perlu upaya bersama orang tua dan gereja dan seluruh pemimpin bangsa. Apabila pemuda sudah tidak memiliki motivasi hidup yang kuat maka dapat dibayangkan akan menjadi apa jemaat Tuhan di masa depan. Firman Tuhan pengkhotbah 12:1 secara jelas berkata kepada para pemuda bahwa di dalam masa mudanya seharusnya mengingat penciptannya sebelum tiba hari-hari yang malang dan mendekat tahuntahun yang tak ada kesenangan atau masa-masa kesusahan. Mengingat Tuhan berarti menempatkan Tuhan pencipta dalam setiap motivasi dan langkag kehidupanya. Dalam kenyataannya pada orang tua, gereja dan pemerintah saat ini belum mampu memahami persoalan kehidupan rohani pemuda yang merosot ini dan membiarkan pemuda berjalan sendiri tanpa pemimpin dalam pencarian identitas dan destini mereka. Hal ini merupakan suatu masalah yang perlu dipecahkan dan diselesaikan supaya pemuda bertumbuh rohaninya dan dapat menjadi generasi penerus hereja serta membawa gereja ke kehidupan yang damai sejahtera dimasa depan. Melihat hal tersebut, meningkat kehidupan rohani pemuda melalui pertumbuhan rohani menjadi suatu prioritas agar pemuda dapat berdiri teguh di atas kebenaran Firman Tuhan serta menyadari tugas dan tanggung jawabnya sebagai generasi penerus yang menjadi harapan gereja, bangsa, dan negara.

Dengan keadaan seperti itu kaum muda membutuhkan pelayan Tuhan yang benarbenar ingin meningkatkan kerohanian pemuda untuk pembentukan kerohanian mereka, 
karena generasi muda merupakan pemegang kendali arah pelayanan ke depan. Ketika generasi muda dilayani dengan baik dan kerohanian mereka mulai bertumbuh dengan sebaik mungkin, maka gereja akan bisa maju dan berkembang dan membawa perubahan bagi jemaat yang lain. Ketika pengurus jemaat melalaikan pelayanan kepada kaum muda, maka sudah dipastikan bahwa keadaan pelayanan gereja akan mengalami kemunduran yang sangat mempengaruhi rohani jemaat khususnya bagi pemuda gereja. Dengan demikian, bahwa setiap pelayan Tuhan dalam gereja harus memperhatikan dan mempedulikan pelayanan kepada pemuda, tidak dipungkiri lagi sesuai dengan fakta dan berdasarkan kesaksian dari pemuda di gereja setempat bahwa badan pengurus jemaat kurang menjalankan perannya sebagai pelayan Tuhan, kurang memberi perhatian terhadap kaum muda sehingga kerohanian mereka tidak mengalami pertumbuhan dan mengalami kemunduran.

Dapat dikatakan bahwa keterlibatan kaum mudah dalam pelayanan di gereja berpengaruh sangat signifikan terhadap kehidupan spiritualitas didik oleh karena itu perlu adanya usaha untuk mempertahankan dan meningkatkan persentase kehidupan keterlibatan tersebut. Lalu hal-hal apa saja yang dapat membuat kaum muda ikut dalam pelayanan di gereja jika dikelompokkan terdapat dua faktor utama yang secara cukup signifikan dapat membuat kaum muda yang rutin ke gereja untuk ikut pelayanan yaitu gereja dan orang tua.

\section{Gereja}

Gereja adalah pihak yang paling berpengaruh mempengaruhi pemuda untuk ikut tidaknya dalam pelayanan kaum muda yang merasa bahwa gereja mendorong untuk terlibat pelayanan akan cenderung lebih mungkin untuk terlibat pelayanan. Selain dorongan secara aktif yang diberikan oleh Gereja ada juga mereka yang tergerak karena mendapatkan manfaat dari gereja itu sendiri. Mereka yang menemukan teman sejati atau komunitas akan cenderung lebih mungkin untuk ikut melayani. Sedangkan mereka yang mendapat manfaat dari program-program Gereja, baik itu khotbah hari Minggu, Bible study seminar maupun diskusi akan lebih mungkin untuk terlibat dalam pelayanan dibandingkan dengan yang tidak mendapat apa-apa.

\section{Orang Tua}

Orang tua sebagai lingkungan terkecil dan roll model juga cukup berpengaruh bagi generasi muda untuk aktif dalam pelayanan di gereja. Mereka yang orang tuanya sangat rajin beribadah akan lebih mungkin untuk terlibat melayani, sedangkan mereka yang sangat aktif dalam pelayanan cenderung lebih mungkin untuk aktif melayani selain itu juga mereka yang spiritualitasnya dibimbing dengan baik oleh orang tuanya akan cenderung lebih mungkin untuk ikut pelayanan. 
Lalu apa yang dilakukan?

\section{Hamba Tuhan Perlu Mengkomunikasikan Visi Yang Besar Dan Menentang Bagi Generasi Muda}

Hasil dalam penelitian ini menyatakan bahwa kaum muda masa kini membutuhkan fisik yang besar dan menantang untuk lebih memahami hal ini Mari kita melihat Penelitian pada kaum muda di Jemaat Pabuaran hasil penelitian tersebut menunjukkan bahwa generasi $\mathrm{Z}$ adalah generasi yang paling berorientasi pada kesuksesan titik mereka menganggap bahwa pencapaian personal baik pendidikan maupun pekerjaan adalah hal yang paling utama dalam hidupku melebihi keluarga dan agama. Tanda paling kedewasaan saling utama bagi mereka adalah kebebasan secara finansial jauh melebihi kedewasaan emosional dan usia. Hal yang ingin mereka capai sebelum usia 30 antara lain Mengejar Mimpi, menikmati hidup sebelum menjalankan tanggung jawab sebagai orang dewasa, dan mencari jati diri. Jika fenomena ini juga terjadi di Indonesia, akan sangat Menjelaskan alasan mengapa kaum muda saat ini suka dengan gereja atau khotbah yang memberi visi besar dan menantang karena sesuai dengan kebutuhan atau target dalam kehidupan mereka. Dengan adanya kesesuaian antara Apa yang ditawarkan gereja dengan kebutuhan kaum muda serta hasil berupa semakin berkembangnya kaum muda karena berusaha mewujudkan tujuan besar dalam hidup mereka tersebut maka gereja telah memberikan manfaat yang positif bagi generasi muda titik seperti yang telah dijelaskan sebelumnya jika kemudian mendapat manfaat dari gereja maka mereka akan lebih mudah untuk ikut dalam pelayanan yang ada di gereja.

\section{Komunikasi Yang Rutin Dengan Digital Media Atau Omnichannel}

Media komunikasi sangat penting dalam mengajak kaum muda untuk berpartisipasi dalam pelayanan, pemilihan media yang tepat serta cara yang sesuai dengan gaya hidup kaum muda akan menciptakan komunikasi yang baik dan efektif antara gereja dan Pemuda. Salah satu dari kehidupan di masa ini adalah kita dapat berkomunikasi dengan para remaja dan pemuda dimanapun dan kapanpun tidak hanya menunggu saat bertemu di gereja. Ini merupakan peluang yang besar bagi gereja untuk membangun komunikasi melalui hal-hal tersebut gereja dapat memanfaatkan kemajuan teknologi dan perubahan gaya hidup ini untuk menjalin hubungan dengan kaum muda gereja serta mengajak mereka untuk bergabung dalam pelayanan gereja. Sudah saatnya gereja melakukan komunikasi melalui internet atau dunia digital baik melalui website media chatting atau WhatsApp LINE dan lain-lainnya maupun media sosial Instagram lain dan sebagainya. Yaitu semasa hidupnya menghabiskan waktu banyak untuk dengan para muridnya. Yesus memberikan pemaknaan hidup yang baru dan mentransformasi hidup mereka ini adalah metode penggembalaan yang dipakai oleh Yesus Pada masa itu memang pada masa kini hal tersebut sulit dilakukan karena perbedaan sosiologis dan budaya akan tetapi dengan kemajuan penggunaan internet pada masa ini para hamba tuhan memiliki lebih banyak waktu untuk melakukan 
penggembalaan pada kaum muda karena dapat dilakukan dimana saja dan kapan saja jika memanfaatkan segala media digital yang tersedia.

\section{Pembentukan Kepanitiaan Untuk Berbagai Program Camp Atau Program Pelayanan}

Untuk dapat melibatkan semakin banyak pemuda dalam pelayanan, maka dibutuhkan kepanitiaan atau kepengurusan yang cukup untuk menampung dan sesuai dengan kapabilitas dan minat dari kaum muda yang ada di gereja. Kepanitiaan dalam berbagai program kamu dapat menarik minat anak muda, karena dalam sebuah acara kan pasti dibutuhkan berbagai macam talenta seperti kreativitas acara dekorasi musik dan lain sebagainya. Mereka bisa mengaktualisasikan diri mereka dan terutama tentang mereka dalam kepanitiaan tersebut. Selain itu juga perlu membuka peluang bagi kaum muda untuk melayani berbagai program pelayanan mingguan agar mereka dapat menyalurkan talenta dan sekaligus menghargai keberadaan mereka dalam gereja titik penting untuk membuat mereka merasa dihargai dan dibutuhkan dalam pelayanan di gereja tentu saja membuat mereka merasa dibutuhkan bukan dalam artian pelayanan bertanggung jawab pada generasi muda tetapi lebih menganggap kesetaraan atas keberadaan mereka di gereja bukan sebagai Jemaat. Tentu saja jika kaum muda sering terlibat dalam pelayanan Semakin banyak teman dan komunikasi dalam gereja yang mereka miliki hal ini membuat mereka memiliki komunitas yang baik dan juga mereka semakin aktif melayani di gereja.

\section{KESIMPULAN}

Pemuda sebenarnya memiliki vitalitas untuk bertumbuh dan berkembang baik secara fisik, intelektual, sosial, emosionaldan spiritual sehingga tugas pelayanan gereja yang dibutuhkan adalah mendampingi dan menuntun generasi muda dan melibatkan dalam pelayanan serta memahami panggilanya di tengah-tengah arus zaman. Menjadi Agen penggerak Tubuh Kristus yang bertumbuh. Pemuda yang telah di bina dengan baik akan menghasilkan pemuda dengan iman yang dewasa. Pemuda yang dewasa secara rohani bukan saja bisa bertumbuh fan di libatkan dalam tugas pelayanan gereja, tetapii juga dapat menjadi agen penggerak bagi pertumbuhan iman tubuh kristus secara keseluruhan. Penulis sangat membutuhkan kritikan serta saran untuk penulisan penelitian yang lebih baik dan lebih bermanfaat.

\section{REFERENSI}

Hutahayan Denny. Peran kepemimpinan spiritual dan media sosial pada rohani pemuda di gereja batak karo protestan (GBKP) cililitan. (deepublish: grub penerbitan cv budi utama,2012)

https://remaja sabda.org peran pemuda dalam gereja.

Silalahi Sabungan Tomson . Dkk. Pemuda milenial. (CV Jejak, 2019) 
http://www.tanyaalkitab.com 2013/02/kaum-muda-masa-depan- gereja.html http//bilanganresearch.com/pentingnya keterlibatan kaum muda dalam pelayanan.html

https://remaja sabda.org peran pemuda dalam gereja. 